Ya. Garachenko, Kharkiv, Ukraine

\author{
EVALUATION OF PERFORMANCE EFFICIENCY \\ OF PACKING A GROUP OF PRODUCTS IN THE WORKPLACE \\ OF ADDITIVE MACHINE USING A GENETIC ALGORITHM
}

\begin{abstract}
Research results of possibilities of packing a group of 3D-models of products in a layered build space using a genetic algorithm are presented. It is proposed to determine the efficiency of the optimization problem of rational arrangement of 3D-models group in the workspace of additive machines depending on the number of loaded products. Condition for efficient use of the layered build workspace is the minimum number of layers per product and the largest relative filling. Such criteria are important, for example, for SLS/SLM technologies. Examples of evaluation based on the analysis of derived voxel $3 D$ model of the workspace with located products are considered. Industrial products with different geometrical complexity were selected as test $3 D$ models. This approach allowed to perform a comparative analysis of the results depending on the design features of products. The practical realization was performed in the subsystem of packing $3 D$-models in a workspace, which is part of the technological preparation system for the manufacture of complex products by additive methods. This system was developed at the Department of "Integrated Technologies of Mechanical Engineering" named after M. Semko of NTU "KhPI".
\end{abstract}

Keywords: technology planning; additive manufacturing; triangulated model; voxel model, packing.

\title{
Introduction.
}

One of the main optimization tasks of technological preparation of additive processes (Additive Manufacturing) is to determine the rational location of the product in the working area of layered building [1]. The ability to solve this optimization problem significantly depends on the geometric complexity of the products and requirements for effective use of additive machines [2]. When applied to methods such as SLS and SLA, one of the important factors in the effectiveness of layering processes is the degree of filling the workspace with products. The provisional estimate of the product in technological preparation for adaptation to the task of rational location is of interest to ensure the level of efficiency of additive processes of layered building [3].

Literature analysis. Rational placement of products 3D models refers to the problems of packaging, which are characterized by significant complexity of solution $[4,5]$. Product placement problems are solved both for single-build and multi-build of one or more machines (single- or multi-machine) [6].

In the known works various approaches and algorithms on a rational arrangement of products group in a workspace of additive technologies machine are used. The genetic algorithm is one of the most common for solving such a problem [7-9]. 
Choice of rational location of the product in the working space of additive machine, as a rule, is performed by solving the optimization problem based on one or many criteria [6]:

- build height [10];

- surface roughness, support volume [11];

- layering time [12];

- total cost [13];

- profit [14];

- nesting rate [15];

- number of products parts obtained during their decomposition [3].

The main problem is that existing works have not created a methodological basis for a comparative analysis of the effectiveness of algorithms for placing a group of 3D models, taking into account geometric features of products. Initial research of genetic algorithm possibilities for the placement of products with different designs was carried out in [16]. But the problem remains to ensure sufficiently high efficiency of using the workspace of machine in the manufacture of small groups of products in one load.

The purpose of the article is to validate the possibility of effectively performing the optimization problem of rational arrangement of 3D models of products group with complex geometry in the workspace of additive machines using a genetic algorithm.

\section{Research methodology.}

A study of the possibilities of the solving optimization problem of packing 3D models of products group was carried out in the system "Technological preparation of materialization of complex products by additive technologies", developed at the Department of Integrated Mechanical Engineering Technologies of NTU "KhPI". This system makes it possible to assess the technological effectiveness of solving technological preparation problems based on the statistical analysis of studied features of polygonal, voxel, and layered 3D models of products [16].

Optimization problem of product placement was performed using voxel product models [3]. Voxel model consists of an ordered set of voxels, which are volume elements with a given location in space (coordinates $\left.x_{V(i)}, y_{V(i)}, z_{V(i)}\right)$. Therefore, the voxel model is a set of elementary volumes $V=\{v[0], v[1], \ldots$ $v[n v]\}=\{v[i]\}$. Voxel models offer a quite simple way to process data for given task.

The developed subsystem provides for the following modes of placing products 3D models in the workspace of AM machine [16]: manual mode; random search (Monte Carlo method); using a genetic algorithm.

Placement of products 3D models in the workspace was carried out with a 
step-by-step check of the free space and fixation of orientation using a genetic algorithm [6, 16, 17].

In fig. 1 are the test 3D models placed in the workspace of Vanguard Si2 SLS machine (made by 3D Systems).

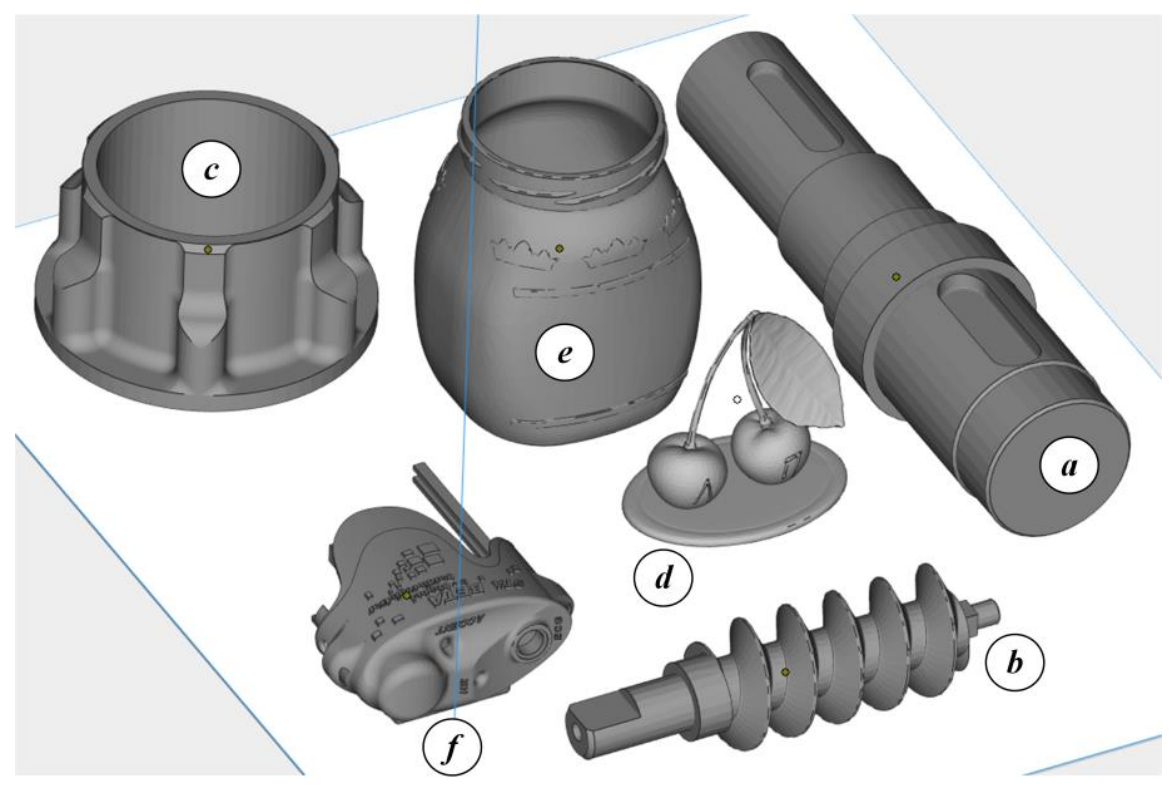

Figure 1 - Test 3D models

$a$ - shaft, $b$ - auger, $c$ - case, $d$ - souvenir, $e$ - container, $f-$ lid

Research of the possibilities of developed algorithm for packing products 3Dmodels (Fig. 1) was carried out by means of comparative analysis by a number of layers $N_{L}$, coefficient of the relative use of the layered build workspace $K_{V}$. Additionally, a relative number of filled and unfilled subspaces was considered to evaluate the efficiency of the algorithm for uniform use of the workspace of the additive machine.

\section{Results of the research.}

The study of developed algorithm capabilities described in [16] was carried out on the example of placing a group of products in an amount of 5-20 pieces. Envelope sizes were set using the example of Vanguard Si2 SLS machine. The estimated flow was considered by the number of building layers, and the efficiency 
of the machine was considered by relative used workspace of layered building. Slicing strategy with a constant building step $h_{i}=0.1 \mathrm{~mm}$, and with a variable step was carried out with the following characteristics: maximum permissible value of deflection from the correct shape $\Delta_{S \max }=0,1 \mathrm{~mm}$ (for a description of slicing method is in [18]). Parameters of genetic algorithm: probability of crossing $p_{c}=80 \%$, mutation probability $p_{m}=2 \%$, population size $N_{p}=20$ pcs., generations limiting number (generations) $N_{g}=50$.

Results of analysis of options for placing 3D-models' groups of products in the workspace of the additive machine (Vanguard Si2 SLS) are shown in table. 1.

Table 1 - Researched features obtained in the analysis of options for 3D-models packing in the workspace

\begin{tabular}{|c|c|c|c|c|c|}
\hline \multirow{2}{*}{$\begin{array}{c}\text { Test 3D-model (overall } \\
\text { dimensions) }\end{array}$} & \multirow{2}{*}{$\begin{array}{l}\text { Number } \\
\text { of } \\
\text { models }\end{array}$} & \multicolumn{2}{|c|}{$\begin{array}{c}\text { Number of building } \\
\text { layers }\end{array}$} & \multirow{2}{*}{$\begin{array}{c}\text { Build } \\
\text { height, } \\
H_{B}\end{array}$} & \multirow{2}{*}{$\begin{array}{c}\text { Coefficient } \\
\text { of space } \\
\text { utilization, } \\
K_{V}\end{array}$} \\
\hline & & $\begin{array}{l}\text { constant } \\
\text { step }\end{array}$ & $\begin{array}{l}\text { variable } \\
\text { step }\end{array}$ & & \\
\hline \multirow{4}{*}{$\begin{array}{l}\text { Shaft } \\
\left(60 \times 216 \times 60 \mathrm{~mm}^{3}\right)\end{array}$} & 5 & 600 & 424 & 61.0 & 0.244 \\
\hline & 10 & 1816 & 1481 & 182.6 & 0.163 \\
\hline & 15 & 2958 & 2086 & 251.5 & 0.178 \\
\hline & 20 & 3219 & 2813 & 322.9 & 0.184 \\
\hline \multirow{4}{*}{ Auger $\left(40 \times 144 \times 40 \mathrm{~mm}^{3}\right)$} & 5 & 582 & 503 & 61.2 & 0.042 \\
\hline & 10 & 1020 & 901 & 104.9 & 0.049 \\
\hline & 15 & 1387 & 1255 & 141.7 & 0.055 \\
\hline & 20 & 1317 & 1226 & 134.68 & 0.077 \\
\hline \multirow{4}{*}{ Case $\left(210 \times 210 \times 125 \mathrm{~mm}^{3}\right)$} & 5 & 1297 & 679 & 132.2 & 0.034 \\
\hline & 10 & 2342 & 1279 & 236.7 & 0.038 \\
\hline & 15 & 3917 & 2156 & 393.0 & 0.034 \\
\hline & 20 & 4092 & 2452 & 413.1 & 0.043 \\
\hline \multirow{4}{*}{ Souvenir $\left(73 \times 51.3 \times 70.1 \mathrm{~mm}^{3}\right)$} & 5 & 1072 & 911 & 110.1 & 0.008 \\
\hline & 10 & 774 & 633 & 80.2 & 0.021 \\
\hline & 15 & 1473 & 1309 & 151.1 & 0.017 \\
\hline & 20 & 1475 & 1341 & 150.5 & 0.023 \\
\hline \multirow{4}{*}{$\begin{array}{l}\text { Container } \\
\left(102 \times 93.6 \times 125.5 \mathrm{~mm}^{3}\right)\end{array}$} & 5 & 1005 & 469 & 104.0 & 0.014 \\
\hline & 10 & 2054 & 954 & 208.9 & 0.014 \\
\hline & 15 & 4245 & 2380 & 428.1 & 0.010 \\
\hline & 20 & 3460 & 2353 & 347.5 & 0.016 \\
\hline \multirow{4}{*}{ Lid $\left(83.9 \times 101.3 \times 43.2 \mathrm{~mm}^{3}\right)$} & 5 & 806 & 738 & 84.3 & 0.016 \\
\hline & 10 & 1357 & 1285 & 139.5 & 0.019 \\
\hline & 15 & 1883 & 1817 & 192.1 & 0.021 \\
\hline & 20 & 2055 & 2001 & 209.3 & 0.025 \\
\hline
\end{tabular}

Analysis of research characteristics, given in table. 1 shows a clear advantage of the approach to load more products into the machine workspace. The exception 
is the shaft and container 3D models. For a shaft 3D model, it is not possible to increase the efficiency of manufacturing. This is due to rather large overall dimensions in relation to the working space dimensions. This circumstance does not allow efficient use of the machine's workspace. The explanation for the container can be the fact that the model belongs to thin-walled products. In this case, regardless of the number of models placement, it is impossible to achieve a noticeable increase of $K_{V}$ coefficient. We can also suppose that $K_{V}$ coefficient is slightly dependent on the choice of a packing algorithm. Models with more complex geometry - auger, souvenir, lid show an essential increase of $K_{V}$ with an increase in the number of loaded products. Container and case show an essential reduction in the number of layers for adaptive slicing strategy relative to constant step (common slicing). This circumstance can be explained by greater initial efficiency from the task performance of rational orientation of part according to the optimization criterion of minimum of the area with greatest deviations from correct surface shape.

Comparative analysis of the obtained results (table. 1) was carried out according to graphs shown in Fig. 2.

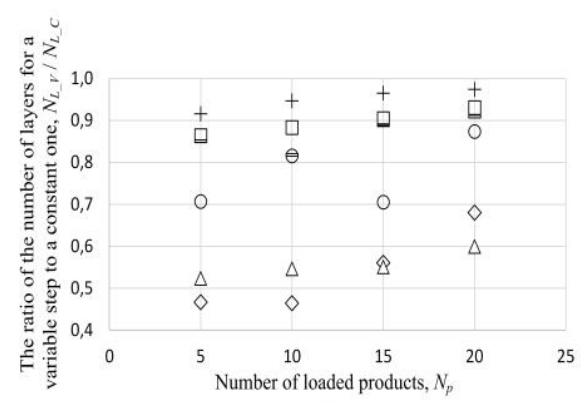

a)

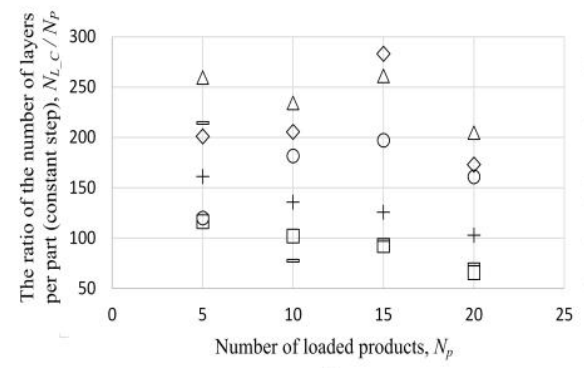

c)

- - shaft; $\square$ - auger; $\Delta$ - case; - - souvenir; $\diamond$ - container; + - lid

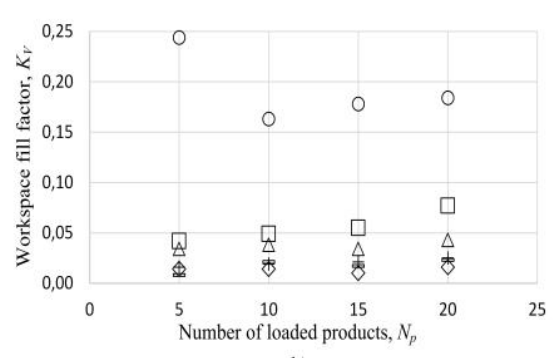

b)

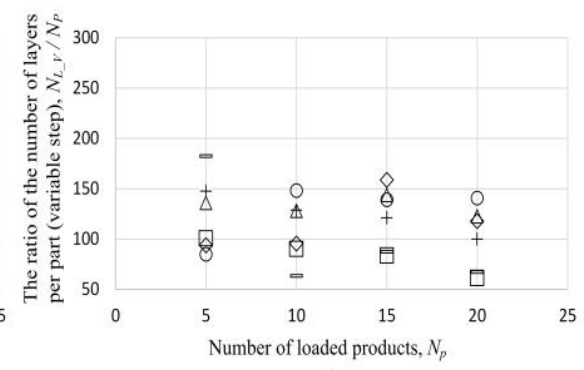

d)

Figure 2 - Dependences of researched features on the number of loaded parts 
Ratio dependence of the number of layers obtained by different cutting strategies $N_{L_{-} V} / N L_{-} C$ on the number of parts loaded into the workspace $N_{p}$, shown in Fig. $2 a$. It allows to you identify the conditions for the greatest efficiency of adaptive slicing in comparison with constant building steps. Using adaptive slicing for loads of the adaptive machine with a small number of parts is most successful. Best results are obtained for container and case.

Analysis of filling factor of the workspace with models (Fig. 2b) shows a significant difference for shaft from other models.

Fig. $2 c, d$ shows graphs of the influence of loaded models' numbers on a relative number of building layers on one model. It is known, that building time and a number of layers are approximately linearly related (within the framework of using the same slicing strategy with the same parameters) for additive methods such as SLS, SLM, SLA, DLP, etc. [19]. Therefore, obtained dependencies are of interest for identifying conditions for increasing productivity of additive processes. The minimum ratio $N_{L_{-} C} / N_{p}$ and, accordingly, $N_{L_{-} V} / N_{p}$ are observed for auger and souvenir. At the same time, increased productivity, i.e. minimization of building time will be ensured with a larger load of these models. In general, for all test 3D models, there is a tendency to increase productivity of layered building processes and fill factor of the workspace of the additive machine.

As a result of research, the following recommendations were obtained to improve the efficiency of using additive installation at stage of placing products in the workspace using a genetic algorithm:

- for products like a shaft and auger, the workspace of the additive machine should not be filled to the maximum;

- greatest efficiency of adaptive slicing is provided for products with complex surface geometry and therefore they should be pre-oriented according to criterion of minimizing surface with greatest deviations;

- for products with complex surface geometry, it is necessary to fill the workspace of the additive machine as much as possible.

Approbation of the algorithm using the example of packing a small group of 3D models of complex products has demonstrated some improvement in researched features due to loading a kit of parts into the workspace of the additive machine. In some cases, it was possible to reduce specific number of construction layers per part within the range of $9.9 \div 65.6 \%$. At the same time, the time spent on the implementation of the optimization problem of parts packing increases significantly (preliminary researched results are presented in [16]).

\section{Conclusions.}


Results of research of genetic algorithm possibilities for effectively solving the problem of packing a group of products $3 \mathrm{D}$ models in the workspace to fill it as much as possible showed an increase in productivity of their layered building. At the same time, the time spent does not increase so significantly compared to the task of packing a small 3D models group located directly on the platform of the additive machine.

Based on the analysis of researched features of the workspace with placed 3D models in the workspace, rational quantities of loaded parts have been identified, depending on their design features. Under certain conditions, it is possible to reduce specific number of building layers per part to $65.6 \%$.

Findings create the basis for further consideration of joint solution of the problems of rational orientation and placement of a large group of complex products in the workspace using a genetic algorithm to expand possibilities of technological preparation of additive manufacturing.

References: 1. Che Y., Hи K., Zhang Z., Lim A. Machine scheduling with orientation selection and twodimensional packing for additive manufacturing. Computers \& Operations Research, 2021. 130, 105245. doi: 10.1016/j.cor.2021.105245. 2. Chekanin V.A., Chekanin A.V. Solving the Problem of Dense Packing of Objects of Complex Geometry. In: Evgrafov A.N. (eds) Advances in Mechanical Engineering. Lecture Notes in Mechanical Engineering. Springer, Cham, 2022. doi: 0.1007/978-3-03091553-7_12. 3. Garashchenko Y., Rucki M. Part decomposition efficiency expectation evaluation in additive manufacturing process planning. International Journal of Production Research, 2021. 14 p. doi: 10.1080/00207543.2020.1824084. 4. Psiola V.V.: Approximate solution of a 3-dimensional packaging problem based on heuristics. Intelligent systems, 2011. Vol. 1, 83-100 [in Russian]. 5. Stoyan Y., Gi l N., Scheithauer G. Packing of convex polytopes into a parallelepiped. Preprint. Dresden. MATH-NM-062004, 2004. 32 pages. 6. Oh Y., Witherell P., Lu Y., Sprock T. Nesting and Scheduling Problems for Additive Manufacturing: A Taxonomy and Review. Additive Manufacturing, 2020. 101492. 7. Aguilar-Duque J.I., Balderrama-Armendáriz C.O., Puente-Montejano C.A. et al. Genetic algorithm for the reduction printing time and dimensional precision improvement on $3 \mathrm{D}$ components printed by Fused Filament Fabrication. Int J Adv Manuf Technol 115, 2021. 3965-3981. doi: 10.1007/s00170-02107314-w. 8. Li Y.B., Sang H.B., Xiong X., Li Y.R. An Improved Adaptive Genetic Algorithm for TwoDimensional Rectangular Packing Problem. Applied Sciences, 11(1), 2021. 413. 9. Zhao Y., Rausch C., Haas C. Optimizing 3D irregular object packing from 3D scans using metaheuristics. Advanced Engineering Informatics, 47, 2021. 101234. 10. Araújo L.J.P., Panesar A., Özcan E., Atkin J., Baumers M., Ashcroft I. An experimental analysis of deepest bottom-left-fill packing methods for additive manufacturing, Int. J. Prod. Res. 0 (0), 2019. 1-17. doi: 10.1080/00207543.2019.1686187 Nov. 11. Vanek J., et al. PackMerger: a 3D Print volume optimizer, Comput. Graph. Forum 33 (6), 2014. 322-332, doi: 10.1111/cgf.12353 Sep. 12. Luzon Y., Khmelnitsky E. Job sizing and sequencing in additive manufacturing to control process deterioration, IISE Trans. 51 (2), 2019. 181-191. doi: 10.1080/24725854.2018.1460518 Feb. 13. Fera M., Macchiaroli R., Fruggiero F., Lambiase A. A modified tabu search algorithm for the single-machine scheduling problem using additive manufacturing technology,", Int. J. Ind. Eng. Comput. 11 (3), 2020. 401-414. 14. Li Q., Zhang D., Wang S., Kucukkoc I. A dynamic order acceptance and scheduling approach for additive manufacturing on-demand production, Int. J. Adv. Manuf. Technol., 2019. doi: 10.1007/s00170-019-03796-x May. 15. Yang W., Liu $W$., Liu L., Хи A. A genetic algorithm for automatic packing in Rapid prototyping processes, Advanced Intelligent Computing Theories and Applications. With Aspects of Theoretical and Methodological Issues, 2008. pp. 1072-1077. doi: 10.1007/978-3-540-87442-3_132. 
16. Garashchenko Y., Vitiaziev J., Grimzin I. Packing 3D-Models of Products in Build Space of Additive Manufacturing Machine by Genetic Algorithm. Advanced Manufacturing Processes III. InterPartner 2021. Lecture Notes in Mechanical Engineering. Springer, Cham, 2022. P. 67-77. doi: 10.1007/978-3-030-91327-4_7. 17. Kureichik V., Kureichik V., Gladkov L. Genetic algorithms. Moscow: Fizmat-lit, 2010. 368 p. [in Russian]. 18. Garashchenko Y., Zubkova N. Adaptive slicing in the additive manufacturing process using the statistical layered analysis. Advances in Design, Simulation and Manufacturing III. DSMIE 2020. Lecture Notes in Mechanical Engineering. Springer, Cham, 2020. P. 253-263. doi: 10.1007/978-3-030-50794-7_25. 19. Vitjazev Ju.B. Rasshirenie tehnologicheskih vozmozhnostej uskorennogo formoobrazovanija sposobom stereolitografii: Dis... kand. tehn. nauk: 05.02.08, Har'kov, 2004. 228 s.

Ярослав Гаращенко, Харків, Україна

\title{
ОЦІНКА ЕФЕКТИВНОСТІ ВИКОНАННЯ ЗАДАЧІ РОЗМІЩЕННЯ ГРУПИ ВИРОБІВ У РОБОЧОМУ ПРОСТОРІ АДИТИВНИХ УСТАНОВОК З ВИКОРИСТАННЯМ ГЕНЕТИЧНОГО АЛГОРИТМУ
}

\begin{abstract}
Анотація. Представлено результати дослідження можливостей розміщення (упаковки) групи 3D-моделей виробів у робочому просторі пошарової побудови з використанням генетичного алгоритму. Запропоновано визначати ефективність оптимізаційної задачі раціонального розташування групи $3 D$-моделей у робочому просторі адитивних установок у залежності від кількості завантажених виробів. Умовою ефективного використання робочого простору пошарової побудови є мінімальна кількість шарів на виріб та найбільше відносне заповнення. Такі критерії є важливими для таких технологій як SLS/SLM. Розглянуто приклади оцінки ефективності розробленого алгоритму на основі аналізу похідної воксельної $3 D$-моделі робочого простору з розташованими виробами. В якості тестових $3 D$-моделей обрано промислові вироби з різною геометричною складністю поверхонь. Такий підхід дозволив виконати порівняльний аналіз результатів в залежності від конструктивних особливостей виробів. Апробація алгоритму з прикладу розмімення невеликої групи 3D-моделей складних виробів у робочий простір адитивної машини продемонструвала достатньо суттєве поліпшення досліджуваних ознак, щуо впливають на продуктивність процесів та собівартість виготовлення.Практична реалізачія виконувалась у підсистемі раціонального розтамування $3 D$-моделей у робочому просторі, щцо входить до системи технологічної підготовки виготовлення складних виробів адитивними методами. Систему розроблено на кафедрі «Інтегровані технологіі машинобудування» ім. М.Ф. Семка НТУ «ХПІ». Дана система дозволяє виконувати оиінку технологічності конструкиї та ефективності вирішення оптимізаційних задач технологічної підготовки адитивного виробництва на основі статистичного та візуального аналізу досліджуваних (геометричних та технологічних) ознак первісної полігональної, похідної воксельної та кінцевої пошарової $3 D$-моделей виробів.
\end{abstract}

Ключові слова: технологічна підготовка; адитивні технології; тріангуляційна модель; воксельна модель; розміщення групи виробів у робочому просторі; генетичний алгоритм. 